\title{
Radiological/Nuclear Agent Irradiation Source Beam Strength
}

National Cancer Institute

\section{Source}

National Cancer Institute. Radiological/Nuclear Agent Irradiation Source Beam Strength.

NCl Thesaurus. Code C158320.

The energy of the irradiation beam produced by the source. 